\title{
Performance of dairy cows fed diets with similar proportions of undigested neutral detergent fiber with wheat straw substituted for alfalfa hay, corn silage, or both
}

\author{
A. Kahyani, ${ }^{1}$ G. R. Ghorbani, ${ }^{1}$ M. Alikhani, ${ }^{1}$ E. Ghasemi, ${ }^{1}$ A. Sadeghi-Sefidmazgi, ${ }^{1}$ K. A. Beauchemin, ${ }^{2}$ \\ and S. M. Nasrollahi ${ }^{3 *}$ \\ ${ }^{1}$ Department of Animal Sciences, College of Agriculture, Isfahan University of Technology, Isfahan 84156-83111, Iran \\ ${ }^{2}$ Lethbridge Research and Development Centre, Agriculture and Agri-Food Canada, Lethbridge, AB T1J 4B1, Canada \\ ${ }^{3}$ Young Researchers Club, Khorasgan (Isfahan) Branch, Islamic Azad University, Isfahan 81551-39998, Iran
}

\section{ABSTRACT}

This study evaluated the effects of feeding diets that were formulated to contain similar proportions of undigested neutral detergent fiber (uNDF) from forage, with wheat straw (WS) substituted for corn silage (CS), alfalfa hay $(\mathrm{AH})$, or both. The diets were fed to lactating dairy cows and intake, digestibility, blood metabolites, and milk production were examined. Thirtytwo multiparous Holstein cows (body weight $=642 \pm$ $50 \mathrm{~kg}$; days in milk $=78 \pm 11 \mathrm{~d}$; milk production $=56$ $\pm 6 \mathrm{~kg} / \mathrm{d}$; mean \pm standard deviation) were used in a randomized block design with 6 -wk periods after a 10 -d covariate period. Each period consisted of $14 \mathrm{~d}$ of adaptation followed by $28 \mathrm{~d}$ of data collection. The control diet contained $\mathrm{CS}$ and $\mathrm{AH}$ as forage sources $(\mathrm{CSAH})$ with $17 \%$ of dietary dry matter as uNDF after $30 \mathrm{~h}$ of incubation $\left(\mathrm{uNDF}_{30}\right)$. Wheat straw was substituted for AH (WSCS), CS (WSAH), or both (WSCSAH) on an $\mathrm{uNDF}_{30}$ basis, and beet pulp was used to obtain similar concentrations of NDF digestibility after $30 \mathrm{~h}$ of incubation $\left(\mathrm{NDFD}_{30}=44.5 \%\right.$ of $\left.\mathrm{NDF}\right)$ across all diets. The 4 diets also contained similar concentrations of net energy for lactation and metabolizable protein. Dry matter intake was greatest for WSCS $(27.8 \mathrm{~kg} / \mathrm{d})$, followed by CSAH $(25.7 \mathrm{~kg} / \mathrm{d})$, WSCSAH $(25.2 \mathrm{~kg} / \mathrm{d})$, and WSAH $(24.2 \mathrm{~kg} / \mathrm{d})$. However, yields of milk, $3.5 \%$ fat-corrected milk (FCM), and energy-corrected milk did not differ, resulting in higher FCM efficiency ( $\mathrm{kg}$ of FCM yield $/ \mathrm{kg}$ of dry matter intake) for WSAH (1.83) and WSCSAH (1.79), followed by CSAH (1.69) and WSCS (1.64). Milk protein percentage was greater for CSAH $(2.84 \%)$ and WSCS $(2.83 \%)$ than for WSAH $(2.78 \%)$, and WSCSAH (2.81\%) was intermediate. The

Received April 27, 2019.

Accepted July 31, 2019.

*Corresponding author: smnasrolahi@gmail.com opposite trend was observed for milk urea nitrogen, which was lower for CSAH (15.8 mg/dL), WSCS (15.8 $\mathrm{mg} / \mathrm{dL})$, and WSCSAH $(17.0 \mathrm{mg} / \mathrm{dL})$ than for WSAH $(20 \mathrm{mg} / \mathrm{dL})$. Total-tract NDF digestibility and ruminal $\mathrm{pH}$ were greater for diets containing WS than the diet without WS (CSAH), but digestibility of other nutrients was not affected by dietary treatments. Cows fed WSAH had less body reserves (body weight change = $-13.5 \mathrm{~kg} /$ period) than the cows fed the other diets, whereas energy balance was greatest for those fed WSCS. The results showed that feeding high-producing dairy cows diets containing different forage sources but formulated to supply similar concentrations of $\mathrm{uNDF}_{30}$ while maintaining $\mathrm{NDFD}_{30}$, net energy for lactation, and metabolizable protein constant did not influence milk production. However, a combination of WS and CS (WSCS diet) compared with a diet with CS and $\mathrm{AH}$ improved feed intake, ruminal $\mathrm{pH}$, total-tract NDF digestibility, and energy balance of dairy cows.

Key words: undigested neutral detergent fiber, forage source, dairy cow, straw

\section{INTRODUCTION}

Corn silage (CS) and alfalfa hay (AH) are 2 forage sources commonly used in dairy diets worldwide. Both forages can be highly digestible and therefore promote high intake and milk production (Wang et al., 2014; Ferraretto et al., 2015). However, production of these high-quality forages requires a tremendous area of land and water, which are limited in many regions of the world. Therefore, byproduct feeds and crop residues are frequently used as fiber sources in dairy cow diets.

Wheat straw (WS) is a relatively inexpensive and available fiber source that is produced worldwide as a byproduct of wheat grain production. However, WS is poorly digested in the total-tract of dairy cows; its in vitro NDF digestibility (NDFD) at 30- and 48-h incubations has been estimated as 24 and $37 \%$ of NDF, 
respectively (Spanghero et al., 2010), and it has an estimated TDN content of $47.5 \%$ (NRC, 2001). The low digestibility of WS may compromise milk production, although WS is often used in dairy cow diets as a source of physically effective fiber to promote rumination and elevate ruminal pH (Eastridge et al., 2009). Beet pulp (BP) is another widely available byproduct feed that is highly digestible in the rumen (in vitro NDFD of 76-90\% of NDF for 30- and 48-h incubations; Hoffman and Combs, 2003; Dal Maso et al., 2009) and high in TDN content (69.1\%; NRC, 2001), but it lacks physically effective NDF (Zhang et al., 2010; Naderi et al., 2016).

Digestibility and indigestibility of NDF affect feeding and rumination behavior, ruminal fill, DMI, and milk production (Mertens, 2016). Oba and Allen (1999) indicated that NDFD was positively related to intake and milk production; on average, a 1-percentage-unit increase in in vitro NDFD (incubation times from 24 to $48 \mathrm{~h}$ ) was associated with a $0.17 \mathrm{~kg} / \mathrm{d}$ increase in DMI and a $0.25 \mathrm{~kg} / \mathrm{d}$ increase in $4 \%$ FCM. Recent studies have shown that total-tract NDFD and performance of dairy cows (Fustini et al., 2017) can be accurately predicted from in vitro or in situ estimates of NDFD (Lopes et al., 2015a). The undigested NDF pool after 30-h incubation $\left(\mathbf{u N D F}_{\mathbf{3 0}}\right.$ ) has been related to total mean retention time and gut fill (West et al., 1997), fiber digestibility (Oba and Allen, 1999), and intake potential (Nair et al., 2016).

Previous research has shown that WS, CS, AH, and BP differ widely in content of uNDF (at 30, 240, and $288 \mathrm{~h}$ of incubation), NDFD, and slowly and rapidly digestible NDF fractions (Fustini et al., 2017; Raffrenato et al., 2019). Regardless of NDF content, the NDF fraction of CS typically contains a higher proportion of potentially digestible NDF (pdNDF; calculated as $\mathrm{NDF}-\mathrm{uNDF}_{240}$ or $\mathrm{uNDF}_{280}$ ) than does alfalfa NDF, but pdNDF of $\mathrm{AH}$ typically digests faster than that of CS (Van Soest, 1994). In contrast, WS contains a low amount of pdNDF with a slow rate of digestion (Raffrenato et al., 2019), and BP contains a high level of pdNDF with a rapid rate of digestion (Hoffman and Combs, 2003; Krizsan and Huhtanen, 2013). Therefore, formulating dairy diets on the basis of NDF concentration alone will result in variable concentrations of digestible and undigestible NDF fractions and rates of availability in the rumen. It is not clear what effect these fractions may have on milk production of highproducing dairy cows.

We hypothesized that replacing conventional forage sources (CS and $\mathrm{AH}$ ) with WS in diets fed to highproducing dairy cows would result in similar milk production if diets were formulated to contain similar contents of $\mathrm{uNDF}_{30}$ and NDFD after 30 -h incubation
$\left(\mathbf{N D F D}_{30}\right)$ while maintaining constant $\mathrm{NE}_{\mathrm{L}}$ and $\mathrm{CP}$ contents. Therefore, the study evaluated the effect of feeding diets formulated to supply similar concentrations of $\mathrm{uNDF}_{30}$ to lactating dairy cows, with WS substituted for CS, AH, or both. Beet pulp was incorporated into diets to obtain a similar concentration of $\mathrm{NDFD}_{30}$ across all diets. Effects on feed intake, ruminal fermentation, digestibility, blood metabolites, and milk production were measured.

\section{MATERIALS AND METHODS}

The experiment consisted of an in vivo study in which treatments were based on results from an in situ study that measured NDFD. Both studies were conducted at the Lavark Research Station (Isfahan University of Technology, Isfahan, Iran). Animals were cared for according to the guidelines of the Iranian Council of Animal Care (1995), and the experiment was approved by the Institutional Animal Care Committee for Animals Used in Research.

\section{Forage Preparation}

Alfalfa was harvested from a single field at an advanced stage of maturity ( $~ 50 \%$ bloom), field cured, baled, and chopped (Golchin Trasher Hay Co., Isfahan, Iran) to a $15-\mathrm{mm}$ theoretical length of cut. Corn silage was harvested from a single field using a pull-type chopper (model 965, Claas, Omaha, NE) set to produce particles with an average theoretical chop length of 25 to $30 \mathrm{~mm}$. Whole wheat plants were threshed to separate cereal grains from straw, and the straw was then chopped finely using a theoretical chop length setting of $10 \mathrm{~mm}$ (Golchin Trasher Hay Co.). The WS was reconstituted $24 \mathrm{~h}$ before feeding and before in situ measurements by placing the required amount of dry WS into a large container and slowly adding water during mixing to achieve a theoretical DM content of $25 \%$. The reconstituted WS was transferred to airtight containers.

\section{In Vivo Study: Animals and Experimental Design}

Thirty-two multiparous high-producing Holstein cows $(\mathrm{BW}=642 \pm 50 ; \mathrm{DIM}=78 \pm 11 \mathrm{~d} ; 56 \pm 6 \mathrm{~kg}$ of milk/d at the start of the study; mean \pm SD) were used in a randomized complete block design with 4 treatments (control and 3 diets that contained WS). The cows were assigned to 2 groups (blocks) that were run consecutively due to stall availability. The experiment consisted of a 10- $d$ covariate period, 2 wk of adaptation to the treatment diets, and 4 wk of data collection. Cows were housed in individual pens $(4 \times 4 \mathrm{~m})$ within a 
Table 1. Mean (SD in parentheses) nutrient composition (\% of DM unless otherwise stated) and particle size of forages and beet pulp

\begin{tabular}{|c|c|c|c|c|}
\hline Item & Beet pulp & Wheat straw & Corn silage & Alfalfa hay \\
\hline \multicolumn{5}{|l|}{ Nutrient composition } \\
\hline DM, $\%$ as fed & $90.2(0.52)$ & $93.0(0.48)$ & $26.2(1.05)$ & $95.0(0.82)$ \\
\hline $\mathrm{OM}$ & $92.5(0.18)$ & $90.9(0.93)$ & $93.6(0.08)$ & $88.5(0.09)$ \\
\hline $\mathrm{CP}$ & $10.3(0.17)$ & $2.6(0.21)$ & $7.7(0.12)$ & $13.3(0.15)$ \\
\hline Ether extract & $0.63(0.07)$ & $1.37(0.10)$ & $2.47(0.27)$ & $1.38(0.07)$ \\
\hline $\mathrm{NDF}$ & $35.1(0.06)$ & $82.0(0.05)$ & $53.8(0.04)$ & $52.0(0.02)$ \\
\hline $\mathrm{NFC}^{1}$ & $46.5(0.35)$ & $4.9(0.25)$ & $29.6(0.74)$ & $21.8(0.43)$ \\
\hline Starch & $1.37(0.40)$ & $0.405(0.06)$ & $23.57(1.92)$ & $1.12(0.16)$ \\
\hline Water-soluble carbohydrate & $18.56(1.40)$ & $1.03(0.12)$ & $1.07(0.19)$ & $3.62(0.62)$ \\
\hline Lignin & $2.06(0.50)$ & $8.40(0.20)$ & $3.90(0.30)$ & $9.50(0.73)$ \\
\hline $\mathrm{uNDF}_{30}{ }^{2}$ & $7.7(3.56)$ & $62.4(3.65)$ & $37.3(3.70)$ & $32.0(0.99)$ \\
\hline $\mathrm{NDFD}_{30}, 3 \%$ of NDF & $78.2(3.55)$ & $25.9(2.45)$ & $30.9(4.33)$ & $38.6(1.92)$ \\
\hline $\mathrm{uNDF}_{240}$ & $2.82(0.41)$ & $27.4(0.89)$ & $12.9(0.67)$ & $27.4(0.62)$ \\
\hline $\mathrm{uNDF}_{288}{ }^{24}$ & $2.81(0.39)$ & $26.6(0.87)$ & $12.8(0.68)$ & $27.2(0.57)$ \\
\hline $\operatorname{pdNDF}_{288}, 4 \%$ of NDF & $92.0(1.12)$ & $67.6(1.06)$ & $76.2(1.27)$ & $47.8(1.10)$ \\
\hline $\mathrm{pdNDF}_{288} \mathrm{kd}^{5} \% / \mathrm{h}$ & $7.24(0.04)$ & $1.69(0.07)$ & $2.08(0.06)$ & $4.59(0.06)$ \\
\hline TTNDFD,${ }^{6} \%$ of total NDF & $74.7(0.19)$ & $29.1(0.31)$ & $37.1(0.31)$ & $33.6(0.45)$ \\
\hline \multicolumn{5}{|l|}{ Particle size, $\mathrm{mm}$} \\
\hline$>19$ & $0.75(0.06)$ & $1.00(0.00)$ & $18.3(3.30)$ & $2.00(0.00)$ \\
\hline 8-19 & $65.93(3.00)$ & $56.0(2.24)$ & $56.8(2.06)$ & $33.0(1.41)$ \\
\hline $1.18-8$ & $33.32(3.6)$ & $37.2(1.64)$ & $24.0(1.41)$ & $43.3(0.50)$ \\
\hline$<1.18$ & $0.00(0)$ & $6.20(1.10)$ & $0.97(0.06)$ & $21.8(1.26)$ \\
\hline $\mathrm{GMPL}^{7}$ & $8.38(0.35)$ & $6.70(0.28)$ & $10.6(0.67)$ & $4.12(0.16)$ \\
\hline
\end{tabular}

${ }^{1}$ Calculated as $100-(\% \mathrm{NDF}+\% \mathrm{CP}+\%$ fat $+\%$ ash $)$.

${ }^{2} \mathrm{uNDF}_{30}, \mathrm{uNDF}_{240}$, and $\mathrm{uNDF}_{288}$ are NDF residues after 30-, 240-, and 288-h in situ incubation, respectively.

${ }^{3}$ In situ NDF digestibility after 30 -h in situ incubation.

${ }^{4}$ Potentially digestible NDF after 288 -h in situ incubation.

${ }^{5}$ Potentially digestible NDF fraction digestion rate calculated from TTNDFD model.

${ }^{6}$ Predicted total-tract NDF digestibility using in situ TTNDFD model (Lopes et al., 2015b).

${ }^{7}$ Geometric mean of particle size.

roofed facility with open sides, and clean wood shavings and sand were used for bedding and refreshed daily. Treatment arrangement was based on the amount of $\mathrm{uNDF}_{30}$ in forages (Table 1) as measured using an in situ method, as follows.

\section{In Situ Study}

An in situ study was conducted to measure uNDF and NDFD in forages, BP, and final TMR according to the method described by Bender et al. (2016) and Donnelly et al. (2018; Table 1). Two ruminally cannulated, nonlactating Holstein dairy cows were fed a high-forage TMR diet (25\% AH, 25\% CS, $25 \% \mathrm{WS}, 4.2 \% \mathrm{BP}$, $20.8 \%$ concentrate mix; DM basis) as recommended by Krizsan and Huhtanen (2013). Dried samples were ground to pass the 1-mm screen of a Wiley mill (Arthur $\mathrm{H}$. Thomas, Philadelphia, PA), and $0.5 \mathrm{~g}$ of each sample was weighed into an Ankom F57 bag (Ankom Technology, Macedon, NY) with a pore size of $25 \mu \mathrm{m}$ (Bender et al., 2016). This particular type of bag was selected so that digestibility estimates would be comparable with previous reports (Bender et al., 2016; Su et al., 2017; Donnelly et al., 2018). Samples were incubated in the rumen for 30,240 , and $288 \mathrm{~h}$ in triplicate along with 3 blank bags for each time point. Blanks were sealed Ankom bags containing $0 \mathrm{~g}$ of sample to correct for infiltration of NDF into the sample bags. After removal, samples were soaked in cold water and then washed twice in a commercial washing machine $(1,350 \mathrm{rpm}$; model XQB 22-21GP, Pakshoma, Karaj, Iran) with cold water for $12 \mathrm{~min}$ to ensure that no residue adhered to the bag. This procedure was then duplicated in a second run. The equation for correcting for blanks in the calculation of NDF residue at each time point was as follows (Bender et al., 2016):

$$
\begin{gathered}
\text { NDF residue }(\mathrm{g} / \mathrm{g} \text { of } \mathrm{DM})=[(\text { bag weight }+ \text { residue }) \\
-(\text { bag weight } \times \text { bag correction factor })] / \\
{[(\text { bag weight }+ \text { sample })-\text { bag weight }] .}
\end{gathered}
$$

The bag correction factor represents the average fractional weight change of 3 Ankom blank bags following the NDF washing procedure. The $\mathrm{uNDF}_{30}, \mathrm{uNDF}_{240}$, and $\mathrm{uNDF}_{288}$ were the NDF residues after 30-, 240-, and 288-h incubations, respectively. The value for NDFD at each time point was calculated as 


$$
\begin{gathered}
\text { NDFD }(\% \text { of NDF })= \\
100 \times(\text { initial NDF }- \text { NDF residue }) / \text { initial NDF. }
\end{gathered}
$$

The pdNDF fraction ( $\left.\mathbf{p d N D F} \mathbf{F}_{\mathbf{2 8 8}}\right)$ was calculated as $\mathrm{NDF}-\mathrm{uNDF}_{288}$, and total-tract NDFD was predicted using the model of Lopes et al. (2015b). The model inputs were $\mathrm{pdNDF}_{288}$, its rate of degradation, and its rate of passage. The rate of passage was predicted from a regression model (Krizsan et al., 2010) that accounts for the selective retention of $\mathrm{pdNDF}_{288}$ (Lund et al., 2007), determined using the flux-compartment pool method of Ellis et al. (1994). In the total-tract NDFD model, the predicted value is indexed to a $630-\mathrm{kg}$ dairy cow consuming $23.4 \mathrm{~kg}$ of $\mathrm{DM} / \mathrm{d}$ of a diet containing 30\% NDF. This index sets the rate of passage of $\mathrm{pdNDF}_{288}$ at $2.67 \% / \mathrm{h}$ (Lund et al., 2007; Krizsan et al., 2010). Hindgut digestion of NDF was assumed to be $10 \%$ of total NDF digestion, which was similar to the estimate of hindgut NDF digestion in the Cornell Net Carbohydrate and Protein System Model (Fox et al., 2004). The rate of $\mathrm{pdNDF}_{288}$ degradation was determined using 9 time points $(6,12,24,30,36,48,72$, 96 , and $120 \mathrm{~h}$ ). Natural $\operatorname{logs}$ of the $\mathrm{pdNDF}_{288}$ residue percentages were calculated, and log-residue values less than -3 were considered invalid results and hence were discarded (Bender et al., 2016). The discarded time points were $48,72,96$, and $120 \mathrm{~h}$ for $\mathrm{BP}$ and 72,96 , and $120 \mathrm{~h}$ for $\mathrm{AH}$. A linear regression model was then fit to the natural log residual values versus time, and the inverse natural log of the rate of degradation was determined as the slope of the regression (Donnelly et al., 2018).

\section{In Vivo Study Treatments}

A control diet was formulated to contain CS and AH as forage sources (CSAH; Table 2) and supplied $13.9 \%$ of DM as forage $\mathrm{uNDF}_{30}$ (Table 3). Three treatment diets were formulated to contain $13.9 \%$ of DM as forage $\mathrm{uNDF}_{30}$ using WS substituted for AH (WSCS), CS (WSAH), or both (WSCSAH; Table 1). Pelleted BP was incorporated into the diets so that all 4 contained similar $\mathrm{NDFD}_{30}$ content $(\sim 44.5 \%$ of NDF; Table 3$)$. The diets were formulated using the Cornell Net Carbohydrate and Protein System Model (version 5.0; Fox et al., 2000; Table 1). The protein and energy supplements were adjusted to ensure that diets were similar in $\mathrm{CP}$ and $\mathrm{NE}_{\mathrm{L}}$ contents, but the amounts of $\mathrm{NDF}$, forage $\mathrm{NDF}$, and $\mathrm{uNDF}_{288}$ were allowed to change (Table 2). Feed was supplied twice daily at 1000 and $1800 \mathrm{~h}$ in amounts that allowed $10 \%$ refusals. Diets were manually mixed and weighed into each cow's feed trough, and refusals were manually removed daily and weighed.

Table 2. Ingredient composition of the dietary treatments (values in parentheses are $\%$ of forage undigested $\mathrm{NDF}$ after $30 \mathrm{~h}$ of incubation)

\begin{tabular}{lccccc}
\hline & & \multicolumn{3}{c}{ Diet $^{1}$} \\
\cline { 3 - 5 } Item, \% of DM & Covariate & CSAH & WSCS & WSAH & WSCSAH \\
\cline { 3 - 5 } & & & & & \\
Wheat straw & 0.0 & $0.0(0)$ & $9.04(40)$ & $9.04(40)$ & $9.04(40)$ \\
Corn silage & 21 & $22.0(59)$ & $22.0(59)$ & $6.80(19)$ & $14.4(39)$ \\
Alfalfa hay & 13 & $18.0(41)$ & $0.40(1)$ & $18.0(41)$ & $9.20(21)$ \\
Beet pulp & 8 & 2.00 & 8.40 & 4.64 & 6.56 \\
Barley grain, ground & 15 & 16.0 & 16.0 & 16.0 & 16.0 \\
Corn grain, ground & 20 & 20.0 & 20.0 & 20.0 & 20.0 \\
Meat meal & 0 & 3.80 & 3.80 & 3.80 & 3.80 \\
Soybean meal & 8 & 11.1 & 12.4 & 14.1 & 13.4 \\
Soybean, extruded & 3 & 2.00 & 2.00 & 2.00 & 2.00 \\
Canola meal & 3 & 0.44 & 1.16 & 0.12 & 0.32 \\
Cottonseed & 3 & 0 & 0 & 0 & 0 \\
Fish meal & 1.6 & 0 & 0 & 0 & 0 \\
Energy booster & 1.5 & 1.84 & 1.56 & 2.72 & 2.24 \\
Sodium bicarbonate & 1.1 & 1.00 & 1.00 & 1.00 & 1.00 \\
Calcium carbonate & 0.5 & 0.52 & 0.68 & 0.48 & 0.64 \\
Dicalcium phosphate & 0.1 & 0.08 & 0.16 & 0.08 & 0.16 \\
Magnesium oxide & 0.2 & 0.16 & 0.24 & 0.16 & 0.20 \\
Vitamin-mineral mix ${ }^{2}$ & 0.7 & 0.80 & 0.80 & 0.80 & 0.80 \\
Salt & 0.3 & 0.20 & 0.24 & 0.20 & 0.20 \\
\hline
\end{tabular}

${ }^{1}$ Experimental diets were combinations of different forage sources to achieve similar dietary concentrations of undigested NDF after $30 \mathrm{~h}$ of incubation. CSAH $=0 \%$ wheat straw (WS), $59 \%$ corn silage (CS), and $41 \%$ alfalfa hay $(\mathrm{AH}) ; \mathrm{WSCS}=40 \% \mathrm{WS}, 59 \% \mathrm{CS}$, and $1 \% \mathrm{AH} ; \mathrm{WSAH}=40 \% \mathrm{WS}, 41 \% \mathrm{AH}$, and $19 \% \mathrm{CS}$; WSCSAH $=40 \% \mathrm{WS}, 39 \% \mathrm{CS}$, and $21 \% \mathrm{AH}$.

${ }^{2}$ Contained $2.5 \mathrm{~g} / \mathrm{kg} \mathrm{Fe}, 1.6 \mathrm{~g} / \mathrm{kg} \mathrm{Cu}, 3 \mathrm{~g} / \mathrm{kg} \mathrm{Mn}, 0.1 \mathrm{~g} / \mathrm{kg} \mathrm{Co}, 20 \mathrm{~g} / \mathrm{kg} \mathrm{Mg}, 5 \mathrm{~g} / \mathrm{kg} \mathrm{Zn}, 0.04 \mathrm{~g} / \mathrm{kg} \mathrm{Se}, 0.10 \mathrm{~g} /$ $\mathrm{kg} \mathrm{I}, 3 \mathrm{~g} / \mathrm{kg}$ monensin, $50 \mathrm{~g} / \mathrm{kg}$ Mycosorb (Vetaque, Sirjan, Iran), 10,000,000 IU/kg vitamin A, 250,000 IU/kg vitamin $\mathrm{D}$, and $5,000 \mathrm{IU} / \mathrm{kg}$ vitamin $\mathrm{E}$. 


\section{Intake, Digestibility, and Analyses}

The TMR amounts offered and refused were measured and sampled daily for each cow for $5 \mathrm{~d}$ each week of the data collection period, and daily DMI for each cow was calculated. Representative samples of forages (for each forage, weekly samples were pooled for the study), treatment TMR (pooled by diet within week), and individual refusals (pooled by cow within week) were taken immediately before the morning feeding during the 4-wk collection period. All samples were immediately frozen at $-20^{\circ} \mathrm{C}$ until they were analyzed.

After thawing, the DM concentration of forages, TMR, and refusal samples was determined by drying at $60^{\circ} \mathrm{C}$ in a forced-air oven for $48 \mathrm{~h}$. All samples were ground to pass the 1-mm screen of a Wiley mill (Arthur H. Thomas, Philadelphia, PA) and analyzed for CP using the Kjeldahl method (Kjeltec 1030 Auto Analyzer, Tecator, Höganäs, Sweden; AOAC International, 2006, method 955.04), ether extract (AOAC International, 2006, method 920.39), ash (AOAC International, 2006, method 942.05), and NDF using heat-stable $\alpha$-amylase and sodium sulfite with an Ankom system (Van Soest et al., 1991). The samples of forages, BP, and TMR were also analyzed for the amount of starch (Zhu et al., 2016) and water-soluble carbohydrate (Dubois et al., 1956). Starch was hydrolyzed to glucose using a modified glucoamylase method as described by Zhu et al. (2016), and glucose concentration was analyzed using an enzymatic-colorimetric method. Concentrations of water-soluble carbohydrate were quantified using the phenol-sulfuric acid reaction, and final concentrations of water-soluble carbohydrate were determined colorimetrically using glucose as the standard curve (Dubois et al., 1956). Acid detergent lignin was determined using AOAC International (2006) method 973.18, modified to use $1.0 \mathrm{~g} / \mathrm{sample}$ in Ankom F57 bags (Ankom Technology). Nonfiber carbohydrate was calculated as $100-(\mathrm{CP}+\mathrm{NDF}+$ ether extract + ash $)$. Forage, BP, and TMR samples were used to determine particle size distribution on an as-fed basis, in triplicate, using the Penn State Particle Separator equipped with 3 sieves

Table 3. Mean (SD in parentheses) nutrient composition (\% of DM unless otherwise stated) and particle size of dietary treatments

\begin{tabular}{|c|c|c|c|c|c|}
\hline Item & Covariate & \multicolumn{4}{|c|}{$\operatorname{Diet}^{1}$} \\
\hline \multicolumn{6}{|l|}{ Nutrient composition } \\
\hline $\mathrm{OM}$ & $91.1(0.15)$ & $91.2(0.1)$ & $91.2(0.1)$ & $90.7(0.1)$ & $91.1(0.0)$ \\
\hline $\mathrm{CP}$ & $15.9(0.5)$ & $16.3(0.4)$ & $15.9(0.3)$ & $16.9(0.5)$ & $16.4(0.3)$ \\
\hline $\mathrm{NDF}$ & $31.8(0.6)$ & $30.0(0.4)$ & $30.9(0.6)$ & $31.3(0.4)$ & $31.1(0.5)$ \\
\hline Water-soluble carbohydrate & $4.1(0.48)$ & $3.14(0.47)$ & $3.9(0.52)$ & $3.65(0.45)$ & $3.75(0.40)$ \\
\hline Lignin & $1.93(0.1)$ & $2.1(0.1)$ & $1.8(0.1)$ & $2.2(0.4)$ & $2.0(0.3)$ \\
\hline Forage NDF & $19.0(0.3)$ & $21.2(0.2)$ & $19.5(0.2)$ & $20.4(0.3)$ & $19.9(0.01)$ \\
\hline $\mathrm{NE}_{\mathrm{L}},{ }^{3} \mathrm{Mcal} / \mathrm{kg}$ of DM & 1.70 & 1.65 & 1.66 & 1.65 & 1.65 \\
\hline Forage $\mathrm{uNDF}_{30}, \%$ of DM & $12.3(0.5)$ & $13.9(0.6)$ & $13.9(0.6)$ & $13.9(0.3)$ & $13.9(0.4)$ \\
\hline $\mathrm{uNDF}_{30}^{4}$ & $17.8(1.5)$ & $16.9(0.7)$ & $16.9(1.3)$ & $17.5(1.4)$ & $17.0(1.4)$ \\
\hline$>19$ & $6.0(0.8)$ & $5.0(0.8)$ & $5.6(0.8)$ & $1.5(0.3)$ & $3.8(0.6)$ \\
\hline $8-19$ & $18.4(1.2)$ & $23.6(0.6)$ & $29.0(1.9)$ & $22.3(1.6)$ & $26.3(2.0)$ \\
\hline $1.18-8$ & $43.1(2.5)$ & $56.1(2.1)$ & $49.9(2.2)$ & $62.4(2.1)$ & $59.0(3.2)$ \\
\hline$<1.18$ & $30.8(2.8)$ & $15.0(0.2)$ & $15.0(2.9)$ & $13.6(2.7)$ & $10.8(2.0)$ \\
\hline $\mathrm{GMPL}^{7}$ & $4.18(0.2)$ & $4.3(0.1)$ & $4.6(0.1)$ & $4.0(0.1)$ & $4.6(0.3)$ \\
\hline
\end{tabular}

${ }^{1}$ Experimental diets were combinations of different forage sources to achieve similar dietary concentrations of undigested NDF after $30 \mathrm{~h}$ of incubation. $\mathrm{CSAH}=0 \%$ wheat straw (WS), $59 \%$ corn silage (CS), and $41 \%$ alfalfa hay $(\mathrm{AH}) ; \mathrm{WSCS}=40 \% \mathrm{WS}, 59 \% \mathrm{CS}$, and $1 \% \mathrm{AH}$; WSAH $=40 \% \mathrm{WS}, 41 \% \mathrm{AH}$, and $19 \% \mathrm{CS}$; WSCSAH $=40 \% \mathrm{WS}, 39 \% \mathrm{CS}$, and $21 \% \mathrm{AH}$.

${ }^{2}$ Calculated as $100-(\% \mathrm{NDF}+\% \mathrm{CP}+\%$ fat $+\%$ ash $)$.

${ }^{3}$ Based on tabular values (Fox et al., 2000).

${ }^{4} \mathrm{uNDF}_{30}, \mathrm{uNDF}_{240}$, and $\mathrm{uNDF}_{288}$ are NDF residues after 30-, 240-, and 288-h in situ incubation, respectively.

${ }^{5}$ In situ NDF digestibility after 30 -h in situ incubation.

${ }^{6}$ Potentially digestible NDF after 288-h in situ incubation.

${ }^{7}$ Geometric mean of particle size. 
$(19,8$, and $1.18 \mathrm{~mm}$ ) and a bottom pan (Kononoff, 2002). The geometric mean particle length (GMPL) was calculated according to ANSI (1995; method S424.1).

A fecal sample was collected from the rectum of each cow at 0030, 0830, and $1630 \mathrm{~h}$ on the first and second days of the final week of the experiment (6 samples/ cow) to represent a 24-h feeding cycle. Fecal samples were composited by period and analyzed for nutrient content as described to calculate apparent total-tract digestibilities using dietary $\mathrm{uNDF}_{288}$ as an internal marker.

\section{Ruminal $\mathrm{pH}$}

On the final day of the experiment, ruminal fluid $(\sim 3$ $\mathrm{mL}$ ) was sampled approximately $4 \mathrm{~h}$ after the morning feeding from the ventral sac via rumenocentesis, the technique developed by Nordlund and Garrett (1994). The $\mathrm{pH}$ of the ruminal fluid was immediately determined using a portable digital pH meter (HI 8318, Hanna Instruments, Cluj-Napoca, Romania).

\section{Blood Sampling and Analyses}

On d 3 of wk 3 of sampling, blood samples $(7 \mathrm{~mL})$ were collected $4 \mathrm{~h}$ after the morning feeding via the coccygeal vein using an evacuated tube without anticoagulant. Blood samples were placed on ice immediately after collection and centrifuged at 3,000 $\times g$ for $15 \mathrm{~min}$ at $4^{\circ} \mathrm{C}$. Serum samples were separated and stored in plastic tubes frozen at $-10^{\circ} \mathrm{C}$ until analysis. The concentrations of serum glucose (glucose oxidase-phenol 4-aminoantipyrine peroxidase method, kit no. 96004), cholesterol (cholesterol oxidase-phenol 4-aminoantipyrine peroxidase method, kit no. 96003), BUN (Berthelot method, kit no. 96003), total protein (Biuret method, kit no. 96004), albumin (bromocresol green method, kit no. 96003), aspartate aminotransferase (IFCC method, kit no. 96004), and alkaline phosphatase (DGKC method, kit no. 96004) were measured using an autoanalyzer (Abbott Alcyon 300, Abbott Laboratories, Chicago, IL) and commercial kits (Pars Azmoon Co., Tehran, Iran) according to the manufacturer's instructions. The analyzer was calibrated and controls were assayed daily according to the manufacturer's instructions to ensure acceptable assay performance. Serum BHB (kit no. 441054, Randox Laboratories Ltd., Ardmore, UK), nonesterified fatty acids (kit no. 427888, Randox Laboratories Ltd.), and total antioxidant capacity (kit no. NX2332, Randox Laboratories Ltd.) were determined by commercial colorimetric kits using the same autoanalyzer. The concentration of serum malondialdehyde was determined using the thiobarbituric acid reacting substances method, in which the absorbance of a colored complex that is formed from the reaction of malondialdehyde with 2-thiobarbituric acid in an acid environment is measured at $532 \mathrm{~nm}$ (Wullepit et al., 2012). Globulin concentrations were calculated by subtracting albumin concentrations from total protein.

\section{Milk Yield and Components, BW, BCS, and Back Fat Thickness}

Cows were milked 3 times daily at 0100, 0900, and $1700 \mathrm{~h}$ in a herringbone milking parlor. Milk yield for all cows was recorded and sampled at each milking during the final $5 \mathrm{~d}$ of each sampling week of the study. Milk samples were preserved with potassium dichromate, stored at $4^{\circ} \mathrm{C}$, and submitted to the Isfahan University of Technology Central Milk Testing Laboratory (Isfahan, Iran) for fat, true protein, and lactose analyses using an infrared analyzer (MilkoScan 134 BN, Foss Electric, Hillerød, Denmark; AOAC International, 2006, method 972.16). The yields of 3.5\% FCM and ECM were calculated according to the following NRC (2001) equations:

$$
\begin{aligned}
\mathrm{FCM}= & 0.432 \times \text { milk yield }+16.23 \times \text { fat yield; } \\
\mathrm{ECM}= & 12.82 \times \text { fat yield }+7.13 \times \text { protein yield } \\
& +0.323 \times \text { milk yield } .
\end{aligned}
$$

The MUN content was determined by enzymatic assay (Wilson et al., 1998). Milk was centrifuged at 1,200 $\times g$ for $15 \mathrm{~min}$ at $4^{\circ} \mathrm{C}$, the fat was removed, and the defatted milk was thoroughly mixed and deproteinized by mixing $0.2 \mathrm{~mL}$ of defatted milk with $1.8 \mathrm{~mL}$ of cold $3 \%$ trichloracetic acid with a blender and allowing the mixture to stand for $5 \mathrm{~min}$. The samples were then centrifuged at $1,200 \times g$ for $5 \mathrm{~min}$ at $20^{\circ} \mathrm{C}$, and 0.2 $\mathrm{mL}$ of the supernatant was analyzed for MUN using a colorimetric diacetyl monoxine procedure.

At the beginning (d 0 ) and end of the 6-wk experimental period, cows were weighed and BCS was determined using a 5 -point scale where $1=$ emaciated and 5 = obese (Ferguson et al., 1994). Also, at the beginning (d 5 of wk 1) and end of the 6-wk experimental period, back fat thickness was measured according to Schroder and Staufenbiel (2006) using a portable B-mode ultrasound generator (SonoVet 600V, BCF Technology Ltd., West Lothian, Scotland) with a linear transducer and frequency between 5.0 and $6.5 \mathrm{MHz}$. All the measurements at the beginning were considered as covariates for the measurement at the end of the experiment. 


\section{Statistical Analyses}

Data were analyzed as a randomized complete block (group) design with covariate using the MIXED procedure of SAS (version 9.0, SAS Institute Inc., Cary, NC). The model included block, treatment, week, and interaction of treatment and week as fixed effects and cow within treatment as a random effect. The corresponding value of the dependent variable from the covariate period was considered as a covariate (when available). When week of treatment was included as a repeated measure, compound symmetry structure was used to account for autocorrelated errors. Five covariance structures were tested (compound symmetry, compound symmetry with heterogeneous variance, autoregressive order 1, autoregressive order 1 with heterogeneous variance, and antedependence 1) to select the structure with the lowest Akaike information criterion. For the variables without repeated measures during the study, week and its interaction with treatment were removed from the model. Means were determined using the least squares means statement, and treatment means were compared using the Bonferroni $t$-test option after a significant $(P \leq 0.05)$ overall treatment $F$-test. Treatment differences were declared significant at $P \leq 0.05$, and tendencies were discussed at $0.05<$ $P<0.10$.

\section{RESULTS}

\section{Forages and Diets}

The nutrient composition, in situ NDFD, and particle size distribution of the fiber sources are presented in Table 1. The $\mathrm{uNDF}_{30}$ contents (\% of DM) of the fiber sources were as follows : AH, 32.0; CS, 37.3; WS, 62.4; and $\mathrm{BP}, 7.7$. The $\mathrm{NDFD}_{30}$ contents (\% of NDF) were $38.6,30.9,25.9$, and 78.2 , respectively. The concentration of $\mathrm{uNDF}_{288}$ was not consistent with the ranking of the fiber sources for $\mathrm{uNDF}_{30}$; it was greatest for $\mathrm{AH}$ $(27.2 \%$ of DM) and WS ( $26.6 \%$ of DM), followed by CS $(12.8 \%$ of DM) and then BP $(2.8 \%$ of DM).

The finely chopped WS had a very small (1\%) proportion of particles $>19 \mathrm{~mm}$; the greatest proportion $(56 \%)$ of WS was retained on the 8-mm sieve, resulting in a GMPL of $6.70 \mathrm{~mm}$. In contrast, a large portion of CS material was retained on the 19-mm (18.3\%) and $8-\mathrm{mm}(56.8 \%)$ sieves, resulting in a GMPL of $10.6 \mathrm{~mm}$. Alfalfa hay had the lowest GMPL $(4.12 \mathrm{~mm})$, and most of the material was collected on the 1.18-mm (43.3\%) and $8-\mathrm{mm}(33.0 \%)$ sieves.

As planned, all diets had similar forage $\mathrm{uNDF}_{30}$ $(13.9 \%$ of DM) and forage NDF contents $(\sim 20 \%$ of DM; Table 3). The diet formulations also resulted in relatively similar dietary $\mathrm{uNDF}_{30}(\sim 17 \%$ of $\mathrm{DM})$ and $\mathrm{NDFD}_{30}(\sim 44 \%$ of NDF $)$ contents. The $\mathrm{uNDF}_{288}$ was $9.4,8.1,10.8$, and $8.9 \%$ of DM for CSAH, WSCS, WSAH, and WSCSAH, respectively, and ADL varied minimally from 1.8 to $2.2 \%$ of DM. The contents of pdNDF, starch, and NFC were marginally lower in WSAH than in other diets. The WSAH diet had the lowest proportion of particles that were $>19 \mathrm{~mm}$ and 8 to $19 \mathrm{~mm}$ and the greatest proportion of particles that were 1.18 to $18 \mathrm{~mm}$, whereas the other TMR were fairly similar in particle size distribution.

\section{Intake, Milk Production, Feed Efficiency, and BW Change}

Intake of DM was greater $(P<0.01)$ for WSCS $(27.8$ $\mathrm{kg} / \mathrm{d})$ than for CSAH $(25.7 \mathrm{~kg} / \mathrm{d})$, WSCSAH $(25.2$ $\mathrm{kg} / \mathrm{d})$, and WSAH $(24.2 \mathrm{~kg} / \mathrm{d}$; Table 4). Consequently, NDF intake was greatest for WSCS $(P=0.02)$, whereas the other diets had similar NDF intakes $(P>0.10)$. The DMI of all diets increased over the study (week effect, $P=0.02$ ) as shown in Figure 1, with differences among diets detected starting at wk 4 of feeding. Milk, $3.5 \%$ FCM, ECM, and component yields did not differ among the treatments (Table 4). However, protein concentration $(P=0.01)$ was lower for WSAH than for CSAH and WSCS, with WSCSAH being similar to all diets. Milk yield decreased over the study (week effect, $P<0.01)$ without significant differences among diets (Figure 2). The MUN content was greater $(P<0.01)$ for WSAH $(20.0 \mathrm{mg} / \mathrm{dL})$ compared with the other diets $($ mean $=16.2 \mathrm{mg} / \mathrm{dL})$. Efficiency of milk production (milk yield/DMI) and 3.5\% FCM (3.5\% FCM/DMI) were lowest for WSCS, intermediate for CSAH, and greatest for WSAH and WSCSAH $(P<0.05)$.

During the 6 -wk experimental period, cows fed WSAH lost BW, whereas cows fed CSAH, WSCS, or WSCSAH gained BW $(P=0.04$; Table 5$)$. The BCS and back fat thickness were not affected by the dietary treatments $(P>0.10)$. Calculated energy balance was greater for WSCS $(4.62 \mathrm{Mcal} / \mathrm{d} ; P<0.01)$ compared with the other treatments $(\mathrm{CSAH}=2.11$; WSAH $=$ $0.24 ; \mathrm{WSCSAH}=1.07 \mathrm{Mcal} / \mathrm{d})$.

\section{Ruminal pH, Total-Tract Apparent Digestibility, and Blood Metabolites}

Ruminal $\mathrm{pH}$ was greater $(P=0.04)$ for WSCS than for CSAH, and WSAH and WSCSAH were similar to the other treatments (Table 6). Total-tract apparent digestibly of DM, OM, ether extract, and NFC did not differ among treatments, but total-tract NDFD was greater $(P=0.03)$ for WSCS and WSAH compared with CSAH, with WSCSAH being similar to all diets. 
Table 4. Lactation performance and feed efficiency of dairy cows fed diets with similar concentrations of undigested NDF after $30 \mathrm{~h}$ of incubation from different forage sources

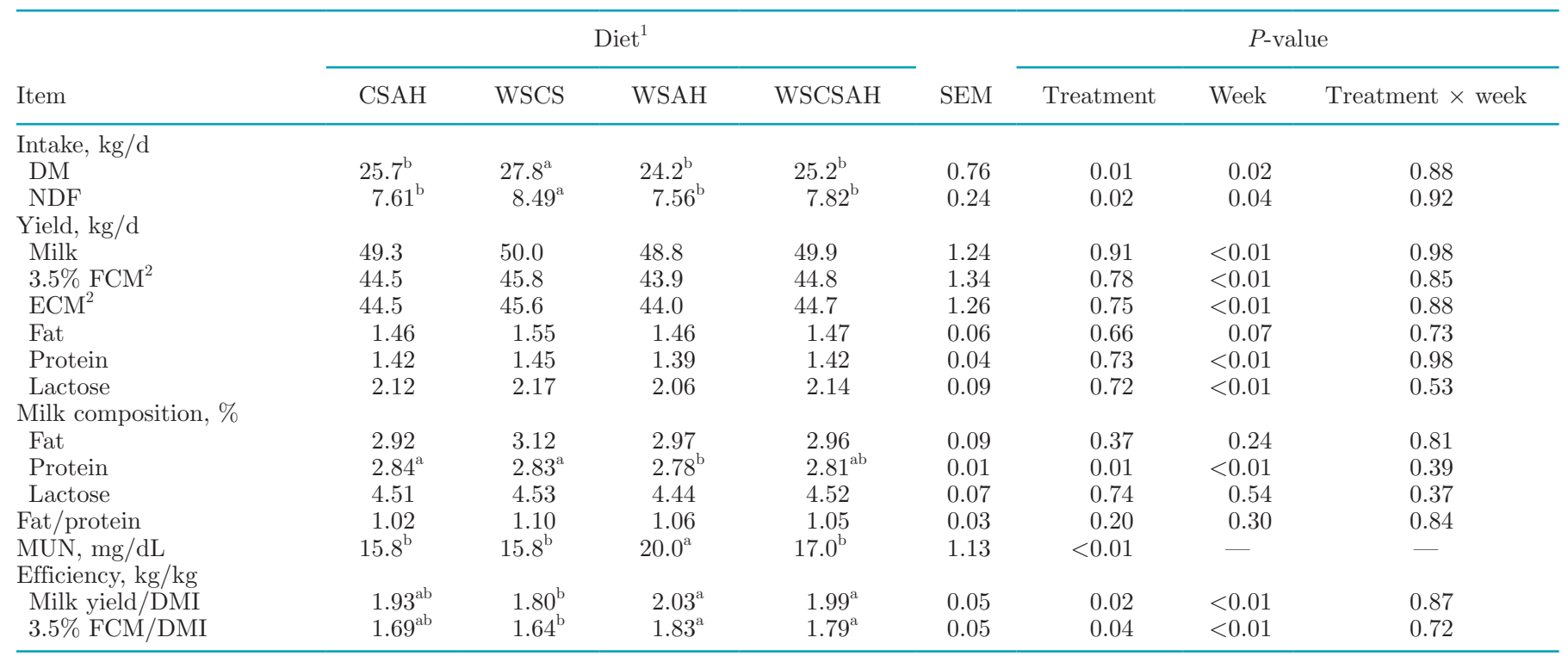

\footnotetext{
a,b Least squares means within a row with different superscripts differ significantly $(P \leq 0.05)$.
}

${ }^{1}$ Experimental diets were combinations of different forage sources to achieve similar dietary concentrations of undigested NDF after $30 \mathrm{~h}$ of incubation. $\mathrm{CSAH}=0 \%$ wheat straw (WS), $59 \%$ corn silage (CS), and $41 \%$ alfalfa hay $(\mathrm{AH})$; WSCS $=40 \% \mathrm{WS}, 59 \% \mathrm{CS}$, and $1 \% \mathrm{AH}$; WSAH $=40 \% \mathrm{WS}, 41 \% \mathrm{AH}$, and $19 \% \mathrm{CS}$; WSCSAH $=40 \% \mathrm{WS}, 39 \% \mathrm{CS}$, and $21 \% \mathrm{AH}$.

${ }^{2} 3.5 \%$ FCM $(\mathrm{kg} / \mathrm{d})=0.432 \times$ milk yield $+16.23 \times$ fat yield ECM $(\mathrm{kg} / \mathrm{d})=12.82 \times$ fat yield $+7.13 \times$ protein yield $+0.323 \times$ milk yield (NRC, 2001).

Concentrations of BUN, glucose, cholesterol, high-density lipoprotein, nonesterified fatty acids, BHB, total protein, albumin, aspartate aminotransferase, alkaline phosphatase, total antioxidant capacity, malondialdehyde, $\mathrm{Na}, \mathrm{K}$, and $\mathrm{Cl}$ in blood were unaffected by dietary treatment (Supplemental Table S1, https://doi .org/10.3168/jds.2019-16869).

\section{DISCUSSION}

Incorporation of WS into the diet of high-producing dairy cows has been the subject of various studies (Poore et al., 1991; Eastridge et al., 2009; Ghasemi, 2013; Wang et al., 2014). However, most of those studies did not consider forage NDFD and UNDF, and thus the diets compared varied in rumen availability of fiber and $\mathrm{NE}_{\mathrm{L}}$ content. Substitution studies are difficult to design because adjustments made (in this case, incorporation of WS) can result in unintended changes in other important dietary characteristics. The present study addressed this issue by substituting WS for $\mathrm{AH}$ or CS in the diet of high-producing dairy cows on the basis of $\mathrm{uNDF}_{30}$ and NDFD contents and balancing the diets to supply similar concentrations of $\mathrm{CP}$ and $\mathrm{NE}_{\mathrm{L}}$. When WS was incorporated in the diet as described, milk production was not affected. Interestingly, the combination of WS and CS (WS substituted for $\mathrm{AH}$ ) increased feed intake, ruminal $\mathrm{pH}$, NDFD, and energy balance of dairy cows compared with a diet with CS and $\mathrm{AH}$. The results are important because in previous experiments the inclusion of WS in diets of highproducing dairy cows on the basis of dietary DM, NDF, or forage NDF generally decreased intake, digestibility, or milk production (Poore et al., 1991; Eastridge et al., 2009; Wang et al., 2014).

Although all diets supplied similar concentrations of forage $\mathrm{uNDF}_{30}$ and $\mathrm{NDFD}_{30}$, DMI was influenced by the dietary treatments. A possible reason for greater DMI of WSCS compared with the other treatments is its lower concentration of dietary $\mathrm{uNDF}_{288}$ (8.1 vs. $9.7 \%$ of DM; WSCS vs. the average of other treatments), which is negatively associated with feed intake (Harper and McNeill, 2015). Cotanch (2015) indicated that the amount of $\mathrm{uNDF}_{240}$ (presumed to be similar to $\mathrm{uNDF}_{288}$ ) consumed is a good indicator of ruminal fill and is inversely related to DMI. The difference in $\mathrm{uNDF}_{288}$ content of diets containing $\mathrm{CS}$ and $\mathrm{AH}$ was attributed to the difference in the original $\mathrm{uNDF}_{288}$ contents of the forages (12.8 vs. $27.1 \%$ of DM, respectively) even though they had similar NDF contents ( 54 vs. $52 \%$ of $\mathrm{DM}$, respectively). The greater intake of diets containing $\mathrm{CS}$ versus $\mathrm{AH}$ is in agreement with Akbari-Afjani et al. (2014) and Lopes et al. (2015a), who reported greater DMI for cows consuming CS-based diets than 


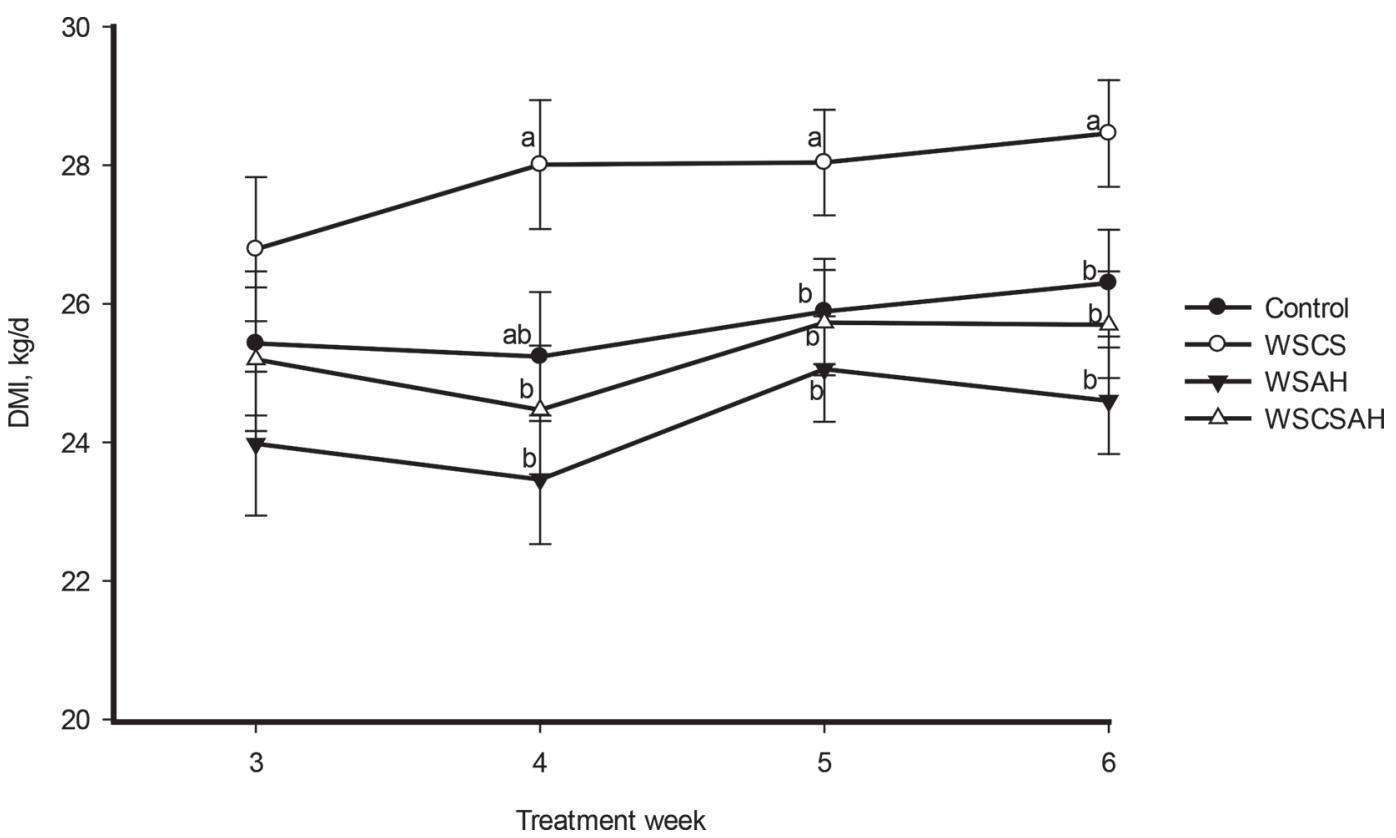

Figure 1. Least squares means of DMI by week for cows fed diets with similar concentrations of undigested NDF after $30 \mathrm{~h}$ of incubation $\left(\mathrm{uNDF}_{30}\right)$ from forage sources. Experimental diets were combinations of different forage sources to achieve similar dietary uNDF $30 \mathrm{concentrations}$ (DM basis). Control $=0 \%$ wheat straw (WS), $59 \%$ corn silage $(\mathrm{CS})$, and $41 \%$ alfalfa hay $(\mathrm{AH})$; WSCS $=40 \% \mathrm{WS}, 59 \%$ CS, and $1 \%$ AH; WSAH $=40 \% \mathrm{WS}, 41 \% \mathrm{AH}$, and $19 \% \mathrm{CS}$; WSCSAH $=40 \% \mathrm{WS}, 39 \% \mathrm{CS}$, and $21 \% \mathrm{AH}$. For each treatment week, least squares means with different letters $(\mathrm{a}, \mathrm{b})$ differ significantly $(P \leq 0.05)$. Error bars indicate SEM.

for cows consuming AH-based diets, but the results contrast with Onetti et al. (2002) and Brito et al. (2006), who observed greater intake of AH-based diets compared with CS-based diets. The discrepancy among studies might be due to the concentration of NDF and $\mathrm{uNDF}_{288}$ in the original forages (Lopes et al., 2015a), which is mainly due to forage maturity (Akbari-Afjani et al., 2014). Therefore, formulating diets to account for $\mathrm{uNDF}_{30}$ content of forage sources may have varying effects on DMI because $\mathrm{uNDF}_{288}$ content may also vary. In addition, greater BP in the WSCS diet compared with the other diets could have contributed to greater DMI because BP has a high amount of pdNDF and greater rate of degradation of pdNDF as well as a high cation exchange capacity (McBurney et al., 1983). In the present study, treatment effects on DMI did not occur until wk 4, in agreement with Lopes et al. (2015a), indicating that the filling effect of NDF sources is delayed, which would not be perceived in short-term studies (i.e., 21-d Latin square designs).

Including WS in the diet increased ruminal $\mathrm{pH}$ regardless of all diets having similar forage NDF, forage $\mathrm{uNDF}_{30}, \mathrm{uNDF}_{30}$ and $\mathrm{NDFD}_{30}$ concentrations, and particle size. It should be noted that a single measure of $\mathrm{pH}$ via rumenocentesis does not represent the diurnal fluctuations due to diet that may have occurred. However, Nasrollahi et al. (2017) reported that rumenocen- tesis and indwelling rumenoreticular probes produced consistent ranking of cows based on pH. Fustini et al. (2016) showed that inclusion of WS could promote rumination and elevate ruminal $\mathrm{pH}$ even in diets with low peNDF content. They suggested that straw, even with short particle size, promotes more chewing per kilogram of NDF compared with other forages. Furthermore, reconstituting chopped WS before feeding, as was done in the present study, might have decreased sorting activity (Teimouri Yansari et al., 2004) by enhancing adherence of straw particles to other feed particles, making it more difficult for cows to sort the TMR.

The improvement in ruminal $\mathrm{pH}$ due to WS may account for the greater total-tract NDFD of cows receiving diets containing WS. Cellulolytic bacteria in the rumen are sensitive to low rumen $\mathrm{pH}$, and therefore decreasing rumen $\mathrm{pH}$ can affect fiber digestibility by diminishing the activity of these bacteria (Russell and Wilson, 1996). However, greater DMI and total-tract NDFD of WSCS compared with CSAH did not improve milk, FCM, or ECM production. In addition, milk production efficiency was decreased in cows fed WSCS as milk production was similar but feed consumption was greater in cows fed WSCS than in cows fed other dietary treatments. Lower milk production efficiency of cows fed WSCS might partly be explained by greater weight gain and energy balance of these cows indicating 


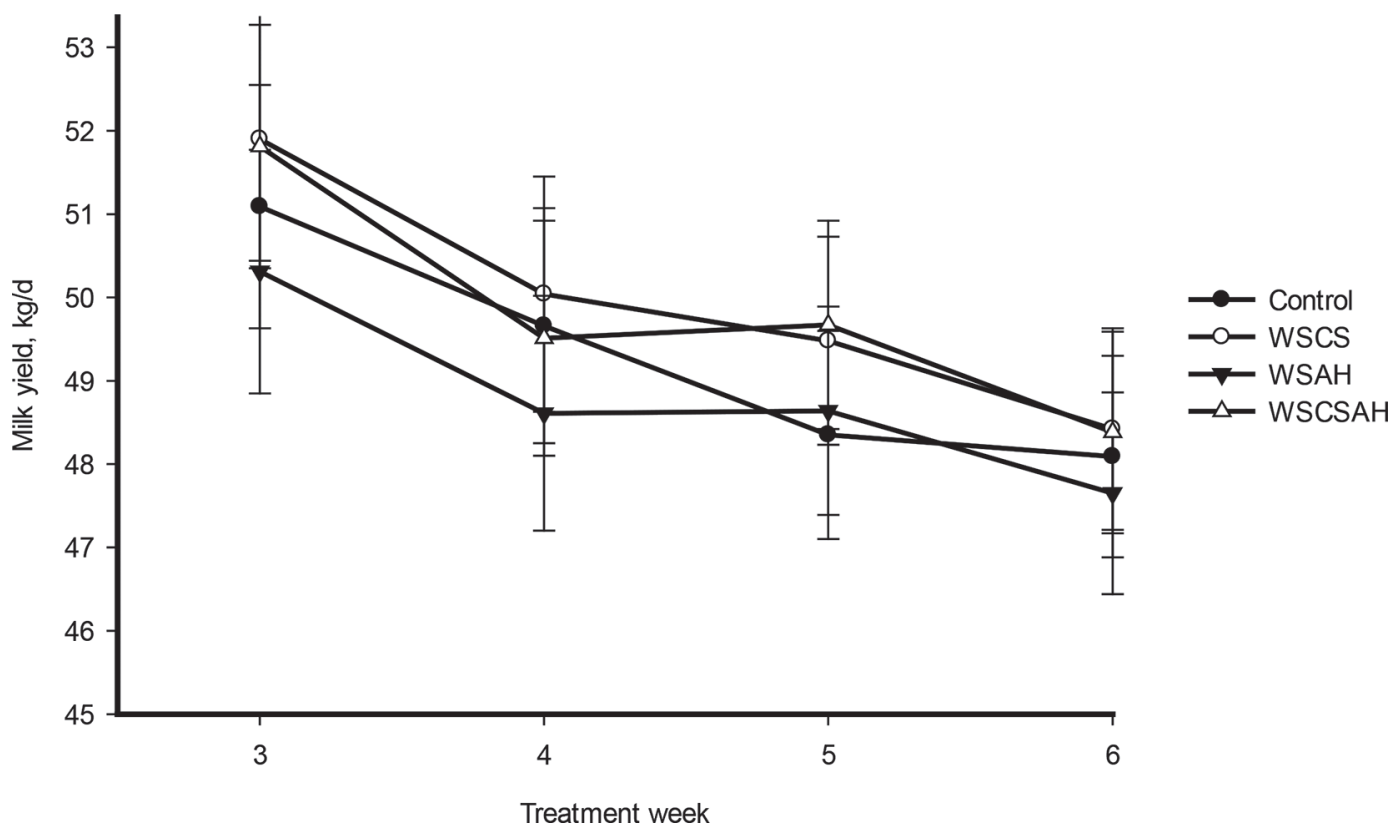

Figure 2. Least squares means of milk yield by week for cows fed diets with similar concentrations of undigested NDF after $30 \mathrm{~h}$ of incubation $\left(\mathrm{uNDF}_{30}\right)$ from forage sources. Experimental diets were combinations of different forage sources to achieve similar dietary $\mathrm{uNDF}_{30}$ concentrations. Control $=0 \%$ wheat straw (WS), $59 \%$ corn silage $(\mathrm{CS})$, and $41 \%$ alfalfa hay $(\mathrm{AH}) ; \mathrm{WSCS}=40 \% \mathrm{WS}, 59 \% \mathrm{CS}$, and $1 \% \mathrm{AH} ; \mathrm{WSAH}=$ $40 \% \mathrm{WS}, 41 \% \mathrm{AH}$, and 19\% CS; WSCSAH = 40\% WS, 39\% CS, and 21\% AH. Error bars indicate SEM.

a potential change in nutrient partitioning among the diets. The difference in $\mathrm{BW}$ gain might be related to gut filling due to greater DMI in WSCS. However, the considerably greater BW change gain and numerically greater back fat thickness of WSCS cows would suggest an improvement in energy status. Nasrollahi et al. (2012, 2014) reported a similar effect of feeding corn grain with a coarse particle size on increasing feed intake and BW gain without improving milk production. They proposed that a change in partitioning of nutri- ents to visceral metabolism and body fat accumulation accounted for the lack of response in milk production. The review by Reynolds (2006) indicates that digestion of starch in the small intestine and its absorption in the form of glucose trigger insulin secretion, causing nutrient partitioning to body reserve accumulation. The CS used in the present study contained unprocessed kernels, which may have led to greater postruminal digestion of starch and body gain compared with diets containing AH. The forage sources may have affected site of starch

Table 5. Body weight change, BCS, and back fat thickness of dairy cows fed diets with similar concentrations of undigested NDF after $30 \mathrm{~h}$ of incubation from different forage sources

\begin{tabular}{|c|c|c|c|c|c|c|}
\hline \multirow[b]{2}{*}{ Item } & \multicolumn{4}{|c|}{ Diet $^{1}$} & \multirow[b]{2}{*}{ SEM } & \multirow[b]{2}{*}{$P$-value } \\
\hline & $\mathrm{CSAH}$ & WSCS & WSAH & WSCSAH & & \\
\hline BW change, ${ }^{2} \mathrm{~kg} /$ period & $8.76^{\mathrm{a}}$ & $11.8^{\mathrm{a}}$ & $-13.5^{\mathrm{b}}$ & $2.88^{\mathrm{ab}}$ & 6.74 & 0.04 \\
\hline $\mathrm{BCS}^{3}$ & 2.71 & 2.80 & 2.68 & 2.88 & 0.11 & 0.38 \\
\hline Back fat thickness ${ }^{4}$ & 26.6 & 30.3 & 28.11 & 29.8 & 1.39 & 0.10 \\
\hline NE balance, ${ }^{5} \mathrm{Mcal} / \mathrm{d}$ & $2.11^{\mathrm{b}}$ & $4.62^{\mathrm{a}}$ & $0.24^{\mathrm{b}}$ & $1.07^{\mathrm{b}}$ & 1.09 & $<0.01$ \\
\hline \multicolumn{7}{|c|}{$\overline{\mathrm{a}, \mathrm{b}}$ Least squares means within a row with different superscripts differ significantly $(P \leq 0.05)$} \\
\hline \multicolumn{7}{|c|}{$\begin{array}{l}{ }^{1} \text { Experimental diets were combinations of different forage sources to achieve similar dietary concentrations of } \\
\text { undigested NDF after } 30 \mathrm{~h} \text { of incubation. CSAH }=0 \% \text { wheat straw (WS), } 59 \% \text { corn silage (CS), and } 41 \% \text { al- } \\
\text { falfa hay (AH); WSCS }=40 \% \text { WS, } 59 \% \mathrm{CS} \text {, and } 1 \% \mathrm{AH} \text {; WSAH }=40 \% \mathrm{WS}, 41 \% \mathrm{AH} \text {, and } 19 \% \mathrm{CS} \text {; WSCSAH } \\
=40 \% \mathrm{WS}, 39 \% \mathrm{CS} \text {, and } 21 \% \mathrm{AH} \text {. } \\
{ }^{2} \text { Over a } 6 \text {-wk period from wk } 1 \text { of adaptation to wk } 4 \text { of sampling. } \\
{ }^{3} \text { Determined using a } 5 \text {-point scale where } 1=\text { emaciated and } 5=\text { obese (Ferguson et al., 1994). } \\
{ }^{4} \text { Measured using ultrasonographic method (Schröder and Staufenbiel, 2006). } \\
{ }^{5} \mathrm{NE} \text { balance }=\left(\text { energy intake, Mcal of } \mathrm{NE}_{\mathrm{L}}\right)-\left[\left(\text { maintenance energy, Mcal of } \mathrm{NE}_{\mathrm{L}}\right)+(\text { milk energy, Mcal of }\right. \\
\left.\left.\mathrm{NE}_{\mathrm{L}}\right)\right] \text { (NRC, 2001). }\end{array}$} \\
\hline
\end{tabular}


Table 6. Rumen $\mathrm{pH}$ and total-tract apparent digestibility in dairy cows fed diets with similar concentration of undigested NDF after $30 \mathrm{~h}$ of incubation from different forage sources

\begin{tabular}{lcccccc}
\hline & \multicolumn{9}{c}{ Diet $^{1}$} & & \\
\cline { 2 - 5 } Item & CSAH & WSCS & WSAH & WSCSAH & SEM & $P$-value \\
\hline pH & $5.74^{\mathrm{b}}$ & $6.29^{\mathrm{a}}$ & $6.08^{\mathrm{ab}}$ & $6.03^{\mathrm{ab}}$ & 0.12 & 0.04 \\
Digestibility, $\%$ & & & & & & \\
DM & 65.5 & 69.4 & 67.9 & 67.7 & 1.66 & 0.25 \\
OM & 68.8 & 72.4 & 70.9 & 70.7 & 1.56 & 0.28 \\
NDF & $38.9^{\mathrm{b}}$ & $49.4^{\mathrm{a}}$ & $46.6^{\mathrm{a}}$ & $43.8^{\mathrm{ab}}$ & 3.05 & 0.03 \\
CP & 66.6 & 68.6 & 71.0 & 70.1 & 1.36 & 0.13 \\
Ether extract & 82.3 & 85.7 & 84.3 & 86.3 & 1.28 & 0.13 \\
NFC & 89.8 & 89.9 & 89.7 & 89.9 & 0.81 & 0.99 \\
\hline
\end{tabular}

$\overline{\mathrm{a}, \mathrm{b}}$ Least squares means within a row with different superscripts differ significantly $(P \leq 0.05)$.

${ }^{1}$ Experimental diets were combinations of different forage sources to achieve similar dietary concentrations of undigested NDF after $30 \mathrm{~h}$ of incubation. $\mathrm{CSAH}=0 \%$ wheat straw (WS), $59 \%$ corn silage (CS), and $41 \%$ alfalfa hay $(\mathrm{AH})$; WSCS $=40 \% \mathrm{WS}, 59 \% \mathrm{CS}$, and $1 \% \mathrm{AH}$; WSAH $=40 \% \mathrm{WS}, 41 \% \mathrm{AH}$, and $19 \% \mathrm{CS}$; WSCSAH $=40 \% \mathrm{WS}, 39 \% \mathrm{CS}$, and $21 \% \mathrm{AH}$.

digestion and thereby lactation efficiency, which is a factor that should be considered when balancing diets for $\mathrm{UNDF}$ and NDFD concentrations.

The lower milk protein concentration of cows fed WSAH corresponded to increased MUN concentration. Milk protein secretion in dairy cows is closely associated with the supply of MP (NRC, 2001), especially microbial protein synthesis (Zhu et al., 2013). Incorporation of WS in dairy cow diets has previously been shown to increase MUN concentration (Farmer et al., 2014; Wang et al., 2014) and decrease milk protein production (Ghasemi, 2013; Wang et al., 2014), although this relationship has not been observed in all studies (Poore et al., 1991; Eastridge et al., 2009). Wang et al. (2014) proposed that feeding WS instead of conventional forages might decrease fermentable carbohydrate concentration of diets and therefore diminish available carbohydrates for ruminal microbial synthesis. Other studies showed that elevating NFC or starch content of diets containing WS prevented a decrease in MUN and milk protein production (Eastridge et al., 2009) or actually increased milk protein content (Poore et al., 1991). The numerically lower NFC and starch contents and presumably lower pectin content (due to less $\mathrm{BP}$ ) in the WSAH diet compared with the other WS-containing diets could have reduced the carbohydrate available for fermentation to capture $\mathrm{N}$ in the rumen. The relatively mature $\mathrm{AH}$ used in the current study may also have contributed to the decrease in protein content of milk. Therefore, fermentable carbohydrate fractions that are important energy sources for microbial protein synthesis and milk protein production need to be considered when adjusting diets for $\mathrm{uNDF}$ and NDFD contents.

Finally, it should be said that some marginal modification of the ingredient composition other than forages was required to make the treatment diets in the present study isocaloric and isonitrogenous while balancing for forage $\mathrm{uNDF}_{30}$. Although these modifications were relatively small, the potential for unintended consequences needs to be considered when reviewing the results of the present study.

\section{CONCLUSIONS}

Inclusion of $\mathrm{WS}$ in isocaloric and isonitrogenous dairy cow diets when substituted for either AH or CS based on NDFD characteristics $\left(\mathrm{uNDF}_{30}\right)$ resulted in similar milk production. However, a combination of WS and CS (WSCS diet) improved feed intake, ruminal $\mathrm{pH}$, total-tract NDFD, and energy balance of dairy cows but reduced the efficiency of milk production. Thus, adding straw to diets containing CS can help improve ruminal function of high-producing dairy cows but may decrease feed efficiency. We conclude that a $\mathrm{uNDF}_{30^{-}}$ based inclusion of WS in dairy cow diets can sustain lactation performance, and combination with CS rather than $\mathrm{AH}$ is recommended.

\section{ACKNOWLEDGMENTS}

This manuscript is contribution no. 95816047 from the Iran National Science Foundation (Tehran, Iran). Authors are thank F. Hashemzadeh-Cigari, A. Piadeh, H. Kahyani, O. Ramezani, M. Asemi, E. Ahmadi, M. Nazari, A. Rajaeerad, M. Safahani-Langarudi, and M. Nemati (Isfahan, Iran), and Feed Processing Co. of Kabileh (Isfahan, Iran) for their technical assistance.

\section{REFERENCES}

Akbari-Afjani, A., A. Zali, M. Gangkhanlou, M. Dehghan-Banadaky, S. M. Nasrollahi, and W. Z. Yang. 2014. Dietary ratios of maize silage to lucerne hay affect feed intake, chewing activity and milk 
production of dairy cows. Anim. Prod. Sci. 54:263-269. https://doi .org/10.1071/AN12214.

ANSI (American National Standards Institute). 1995. Method of determining and expressing fineness of feed material by sieving. Page 461 in ASAE Standards 1995. American Society of Agricultural Engineers, St. Joseph, MI.

AOAC International. 2006. Official Methods of Analysis. 18th ed. AOAC International, Arlington, VA.

Bender, R. W., D. E. Cook, and D. K. Combs. 2016. Comparison of in situ versus in vitro methods of fiber digestion at 120 and 288 hours to quantify the indigestible neutral detergent fiber fraction of corn silage samples. J. Dairy Sci. 99:5394-5400. https://doi.org/ $10.3168 /$ jds.2015-10258.

Brito, A. F., G. A. Broderick, and S. M. Reynal. 2006. Effects of varying dietary ratios of alfalfa silage to corn silage on omasal flow and microbial protein synthesis in dairy cows. J. Dairy Sci. 89:39393953. https://doi.org/10.3168/jds.S0022-0302(06)72436-5.

Cotanch, K. W. 2015. Using 240 hour uNDF in the field. Pages 107110 in Proc. Cornell Nutr. Conf. Feed Manuf., East Syracuse, NY. Cornell Univ., Ithaca, NY.

Dal Maso, M., S. Schiavon, F. Tagliapietra, A. Simonetto, and G. Bittante. 2009. Growth performance and N excretion of double muscled Piemontese bulls fed low protein rations with or without the addition of rumen protected conjugated linoleic acid. Ital. J. Anim. Sci. 8(Suppl. 3):175-177. https://doi.org/10.4081/ijas.2009.s3.175.

Donnelly, D. M., L. C. de Resende, D. E. Cook, R. H. Atalla, and D. K. Combs. 2018. Technical note: A comparison of alkali treatment methods to improve neutral detergent fiber digestibility of corn stover. J. Dairy Sci. 101:9058-9064. https://doi.org/10.3168/jds 2017-14317.

Dubois, M., K. A. Gilles, J. K. Hamilton, P. A. Rebes, and F. Smith 1956. Colorimetric method for determination of sugars and related substances. Anal. Chem. 28:350-356. https://doi.org/10.1021/ ac60111a017.

Eastridge, M. L., P. B. Bucci, and C. V. D. M. Ribeiro. 2009. Feeding equivalent concentrations of forage neutral detergent fiber from alfalfa hay, grass hay, wheat straw, and whole cottonseed in corn silage based diets to lactating cows. Anim. Feed Sci. Tech. 150:8694. https://doi.org/10.1016/j.anifeedsci.2008.08.008.

Ellis, W. C., J. H. Matis, T. M. Hill, and M. R. Murphy. 1994. Methodology for estimating digestion and passage kinetics of forages. Pages 682-756 in Forage Quality, Evaluation and Utilization. G. C. Fahey Jr., M. Collins, D. R. Mertens, and L. E. Moser, ed. Am. Soc. Agron., Crop Sci. Soc. Am., Soil Sci. Soc. Am., Madison, WI.

Farmer, E. R., H. A. Tucker, H. M. Dann, K. W. Cotanch, C. S Mooney, A. L. Lock, K. Yagi, and R. J. Grant. 2014. Effect of reducing dietary forage in lower starch diets on performance, ruminal characteristics, and nutrient digestibility in lactating Holstein cows. J. Dairy Sci. 97:5742-5753. https://doi.org/10.3168/jds.2014 $-7963$.

Ferguson, J. D., D. T. Galligan, and N. Thomsen. 1994. Principal descriptors of body condition score in Holstein cows. J. Dairy Sci. 77:2695-2703. https://doi.org/10.3168/jds.S0022-0302(94)77212 $-\mathrm{X}$.

Ferraretto, L. F., A. C. Fonseca, C. J. Sniffen, A. Formigoni, and R. D. Shaver. 2015. Effect of corn silage hybrids differing in starch and neutral detergent fiber digestibility on lactation performance and total-tract nutrient digestibility by dairy cows. J. Dairy Sci. 98:395-405. https://doi.org/10.3168/jds.2014-8232.

Fox, D. G., L. O. Tedeschi, T. P. Tylutki, J. B. Russell, M. E. Van Amburgh, L. E. Chase, A. N. Pell, and T. R. Overton. 2004. The Cornell Net Carbohydrate and Protein System model for evaluating herd nutrition and nutrient excretion. Anim. Feed Sci. Technol. 112:29-78. https://doi.org/10.1016/j.anifeedsci.2003.10.006.

Fox, D. G.. T. P. Tylutki, K. J. Czymmek, C. N. Rasmussen, and V. M. Durbal. 2000. Development and application of the Cornell University nutrient management planning system. Pages 167-179 in Proc. Cornell Nutr. Conf. Feed Manuf., Rochester, NY. Cornell Univ., Ithaca, NY.

Fustini, M., A. J. Heinrichs, A. Palmonari, and A. Formigoni. 2016. Farm characteristics and TMR particle size issues on Parmigiano
Reggiano farms in Northern Italy. Prof. Anim. Sci. 32:869-873. https://doi.org/10.15232/pas.2016-01550.

Fustini, M., A. Palmonari, G. Canestrari, E. Bonfante, L. Mammi, M. T. Pacchioli, G. C. J. Sniffen, R. J. Grant, K. W. Cotanch, and A. Formigoni. 2017. Effect of undigested neutral detergent fiber content of alfalfa hay on lactating dairy cows: Feeding behavior, fiber digestibility, and lactation performance. J. Dairy Sci. 100:4475-4483. https://doi.org/10.3168/jds.2016-12266.

Ghasemi, E. 2013. Improvement in nutritive value of cereal straw (rice, barley and wheat) by chemical and biological methods for use as ruminant feed. PhD Thesis. Isfahan University of Technology, Isfahan, Iran.

Harper, K. J., and D. M. McNeill. 2015. The role iNDF in the regulation of feed intake and the importance of its assessment in subtropical ruminant systems (the role of iNDF in the regulation of forage intake). Agriculture 5:778-790. https://doi.org/10.3390/ agriculture5030778.

Hoffman, P., and D. K. Combs. 2003. Using NDF digestibility in ration formulation. Focus on Forage 6:1-4.

Iranian Council of Animal Care. 1995. Guide to the Care and Use of Experimental Animals. Vol. 1. Isfahan University of Technology, Isfahan, Iran.

Kononoff, P. J. 2002. The effect of ration particle size on dairy cows in early lactation. PhD Thesis. The Pennsylvania State University, State College.

Krizsan, S. J., S. Ahvenjarvi, and P. Huhtanen. 2010. A meta-analysis of passage rate estimated by rumen evacuation with cattle and evaluation of passage rate prediction models. J. Dairy Sci. 93:5890-5901. https://doi.org/10.3168/jds.2010-3457.

Krizsan, S. J., and P. Huhtanen. 2013. Effect of diet composition and incubation time on feed indigestible neutral detergent fiber concentration in dairy cows. J. Dairy Sci. 96:1715-1726. https://doi .org/10.3168/jds.2012-5752.

Lopes, F., D. E. Cook, and D. K. Combs. 2015a. Effects of varying ratios of corn silage to alfalfa silage on digestion of neutral detergent fiber in lactating dairy cows. J. Dairy Sci. 98:6291-6303. https:// doi.org/10.3168/jds.2014-8662.

Lopes, F., K. Ruh, and D. K. Combs. 2015b. Validation of an approach to predict total-tract fiber digestibility using a standardized in vitro technique for different diets fed to high-producing cows. J. Dairy Sci. 98:2596-2602. https://doi.org/10.3168/jds.2014-8665.

Lund, P., M. R. Weisbjerg, and T. Hvelplund. 2007. Digestible NDF is selectively retained in the rumen of dairy cows compared to indigestible NDF. Anim. Feed Sci. Technol. 134:1-17. https://doi .org/10.1016/j.anifeedsci.2006.05.016.

McBurney, M. I., P. J. Van Soest, and L. E. Chase. 1983. Cation exchange capacity and buffering capacity of neutral-detergent fibres. J. Sci. Food Agric. 34:910-916. https://doi.org/10.1002/jsfa .2740340903 .

Mertens, D. R. 2016. Using uNDF to predict dairy cow performance and design rations. Accessed Mar. 3, 2017. http://www .wiagribusiness.org/fourstatedairy/2016/4_Mertens.pdf.

Naderi, N., G. R. Ghorbani, A. Sadeghi-Sefidmazgi, S. M. Nasrollahi, and K. A. Beauchemin. 2016. Shredded beet pulp substituted for corn silage in diets fed to dairy cows under ambient heat stress: Feed intake, total-tract digestibility, plasma metabolites, and milk production. J. Dairy Sci. 99:8847-8857. https://doi.org/10.3168/ jds.2016-11029

Nair, J., D. P. Yu Christensen, A. D. Beettie, T. McAllister, D. Damiran, N. Preston, L. Fuhr, and J. J. McKinnon. 2016. A nutritional evaluation of common barley varieties grown for silage by beef and dairy producers in western Canada. Can. J. Anim. Sci. 96:598608. https://doi.org/10.1139/cjas-2016-0032.

Nasrollahi, S. M., G. R. Ghorbani, M. Khorvash, and W. Z. Yang. 2014. Effects of grain source and marginal change in lucerne hay particle size on feed sorting, eating behaviour, chewing activity, and milk production in mid-lactation Holstein dairy cows. J. Anim. Physiol. Anim. Nutr. (Berl.) 98:1110-1116. https://doi.org/ 10.1111/jpn.12185

Nasrollahi, S. M., M. Khorvash. G. R. Ghorbani, A. Teimouri-Yansari, A. Zali, and Q. Zebeli. 2012. Grain fermentability and marginal 
changes in forage particle size modulated digestive processes and nutrient intake in dairy cows. Animal 6:1237-1245. https://doi .org/10.1017/S1751731112000122.

Nasrollahi, S. M., A. Zali, G. R. Ghorbani, M. Moradi Shahrbabak, and M. Heydari Soltan Abadi. 2017. Variability in the susceptibility to acidosis among high producing mid-lactation dairy cows is associated with rumen $\mathrm{pH}$, fermentation, feed intake, sorting activity, and milk fat percentage. Anim. Feed Sci. Technol. 228:72-82.

National Research Council. 2001. Nutrient Requirements of Dairy Cattle. 7th rev. ed. Natl. Acad. Sci., Washington, DC.

Nordlund, K. V., and E. F. Garrett. 1994. Rumenocentesis: A technique for the diagnosis of subacute rumen acidosis in dairy herds. Bov. Pract. 28:109-112.

Oba, M., and M. S. Allen. 1999. Evaluation of the importance of NDF digestibility: Effects on dry matter intake and milk yield of dairy cows. J. Dairy Sci. 82:589-596. https://doi.org/10.3168/jds.S0022 -0302(99)75271-9.

Onetti, S. G., R. D. Shaver, M. A. McGuire, D. L. Palmquist, and R. R. Grummer. 2002. Effect of supplemental tallow on performance of dairy cows fed diets with different corn silage:alfalfa silage ratios. J. Dairy Sci. 85:632-641. https://doi.org/10.3168/jds.S0022 -0302(02)74117-9.

Poore, M. H., J. A. Moore, R. S. Swingle, T. P. Eck, and W. H. Brown. 1991. Wheat straw or alfalfa hay in diets with $30 \%$ neutral detergent fiber for lactating Holstein cows. J. Dairy Sci. 74:3152-3159. https://doi.org/10.3168/jds.S0022-0302(91)78500-7.

Raffrenato, E., C. F. Nicholson, and M. E. Van Amburgh. 2019. Development of a mathematical model to predict pool sizes and rates of digestion of 2 pools of digestible neutral detergent fiber and an undigested neutral detergent fiber fraction within various forages. J. Dairy Sci. 102:351-364. https://doi.org/10.3168/jds.2018-15102.

Reynolds, C. K. 2006. Production and metabolic effects of site of starch digestion in dairy cattle. Anim. Feed Sci. Technol. 130:7894. https://doi.org/10.1016/j.anifeedsci.2006.01.019.

Russell, J. B., and D. B. Wilson. 1996. Why are ruminal cellulolytic bacteria unable to digest cellulose at low pH? J. Dairy Sci. 79:1503-1509. https://doi.org/10.3168/jds.S0022-0302(96)76510 -4 .

Schröder, U. J., and R. Staufenbiel. 2006. Invited review: Methods to determine body fat reserves in the dairy cow with special regard to ultrasonographic measurement of back fat thickness. J. Dairy Sci. 89:1-14. https://doi.org/10.3168/jds.S0022-0302(06)72064-1.

Spanghero, M., P. Berzaghi, R. Fortina, F. Masoero, L. Rapetti, C. Zanfi, S. Tassone, A. Gallo, S. Colombini, and J. C. Ferlito. 2010. Technical note: Precision and accuracy of in vitro digestion of neutral detergent fiber and predicted net energy of lactation content of fibrous feeds. J. Dairy Sci. 93:4855-4859. https://doi.org/ 10.3168/jds.2010-3098

Su, H., M. S. Akins, N. M. Esser, R. Ogden, W. K. Coblentz, K. F. Kalscheur, and R. Hatfield. 2017. Effects of feeding alfalfa stem- lage or wheat straw for dietary energy dilution on nutrient intake and digestibility, growth performance, and feeding behavior of Holstein dairy heifers. J. Dairy Sci. 100:7106-7115. https://doi.org/10 .3168/jds.2016-12448.

Teimouri Yansari, A., R. Valizadeh, A. Naserian, D. A. Christensen, P. Yu, and F. Eftekhari Shahroodi. 2004. Effects of alfalfa particle size and specific gravity on chewing activity, digestibility, and performance of Holstein dairy cows. J. Dairy Sci. 87:3912-3924. https: //doi.org/10.3168/jds.S0022-0302(04)73530-4.

Van Soest, P. J. 1994. Nutritional Ecology of the Ruminant. 2nd ed. Cornell Univ., Ithaca, NY.

Van Soest, P. J., J. B. Robertson, and B. A. Lewis. 1991. Methods for dietary fiber, neutral detergent fiber, and nonstarch polysaccharides in relation to animal nutrition. J. Dairy Sci. 74:3583-3597. https://doi.org/10.3168/jds.S0022-0302(91)78551-2.

Wang, B., S. Y. Mao, H. J. Yang, Y. M. Wu, J. K. Wang, S. L. Li, Z M. Shen, and J. X. Liu. 2014. Effects of alfalfa and cereal straw as a forage source on nutrient digestibility and lactation performance in lactating dairy cows. J. Dairy Sci. 97:7706-7715. https://doi .org/10.3168/jds.2014-7961.

West, J. W., G. M. Hill, R. N. Gates, and B. G. Mullinix. 1997. Effects of dietary forage source and amount of forage addition on intake, milk yield, and digestion for lactating dairy cows. J. Dairy Sci. 80:1656-1665. https://doi.org/10.3168/jds.S0022-0302(97)76097 $-1$.

Wilson, R. C., T. R. Overton, and J. H. Clark. 1998. Effects of Yucca shidigera extract and soluble protein on performance of cows and concentrations of urea nitrogen in plasma and milk. J. Dairy Sci. 81:1022-1027. https://doi.org/10.3168/jds.S0022-0302(98)75664 -4 .

Wullepit, N., M. Hostens, C. Ginneberge, V. Fievez, G. Opsomer, D. Fremaut, and S. DeSmet. 2012. Influence of a marine algae supplementation on the oxidative status of plasma in dairy cows during the periparturient period. Prev. Vet. Med. 103:298-303. https:// doi.org/10.1016/j.prevetmed.2011.09.007.

Zhang, S. Z., G. B. Penner, M. Abdelqader, and M. Oba. 2010. Effects of feeding alfalfa hay on chewing, rumen $\mathrm{pH}$, and milk fat concentration of dairy cows fed wheat dried distillers grains with solubles as a partial substitute for barley silage. J. Dairy Sci. 93:3243-3252. https://doi.org/10.3168/jds.2009-3011.

Zhu, L., C. Jones, Q. Guo, L. Lewis, C. R. Stark, and S. Alavi. 2016. An evaluation of total starch and starch gelatinization methodologies in pelleted animal feed. J. Anim. Sci. 94:1501-1507. https:// doi.org/10.2527/jas.2015-9822.

Zhu, W., C. Tang, X. Sun, J. Liu, Y. Wu, Y. Yuan, and X. Zhang. 2013. Rumen microbial protein synthesis and milk performance in lactating dairy cows fed the fortified corn stover diet in comparison with alfalfa diet. J. Anim. Vet. Adv. 12:633-639. 